\title{
Environmental and economic study for a prospective ethanol industry in Fiji
}

\section{Vineet Vishal Chandra*}

Pacific Centre for Environment and Sustainable Development

The University of the South Pacific

Suva, Fiji

Email: chandra_v@usp.ac.fj

Email: vineetvishalchandra@gmail.com

${ }^{*}$ Corresponding author

\section{Sarah L. Hemstock}

The Pacific Community

3rd Floor, Lotus Building,

SPC, Fiji

Email: sarahh@spc.int

Email: sarah_hemstock@hotmail.com

\section{Antoine De Ramon N'Yeurt}

Pacific Centre for Environment and Sustainable Development

The University of the South Pacific

Suva, Fiji

Email: antoine.nyeurt@usp.ac.fj

\section{Dinesh Surroop}

Faculty of Engineering,

Department of Chemical and Environmental Engineering,

University of Mauritius,

Reduit, Mauritius

Email: d.surroop@uom.ac.mu

\begin{abstract}
The study was performed to study the effect of producing ethanol from molasses or sugarcane juice to blend with gasoline and produce E10 fuel for the Fijian car fleet. Two cases were developed to assess the economic and environmental impacts of producing ethanol from these feedstocks and blending with imported motor spirit. It was found to offer many benefits such as Fiji can earn approximately FJ\$ 7.2 million and save $22,730 \mathrm{tCO}_{2}$ emissions annually with providing employment to many. The continuous increase in the importation of motor spirit demands the biofuel policy to be reviewed to encourage (E10) blending locally. Conversion of sugarcane juice to ethanol directly could sustain the current income generated from sugar and molasses exported. This sounds to be future solution to sustain the industry after the end of EU sugar quota and if the sugar price offered thereafter are not profitable.
\end{abstract}


Keywords: sugarcane; molasses; ethanol fuel; emissions; mitigation; Fiji.

Reference to this paper should be made as follows: Chandra, V.V., Hemstock, S.L., N'Yeurt, A.D.R. and Surroop, D. (xxxx) 'Environmental and economic study for a prospective ethanol industry in Fiji', Progress in Industrial Ecology - An International Journal, Vol. x, No. x, pp.xxx-xxx.

Biographical notes: Vineet Vishal Chandra is a $\mathrm{PhD}$ Candidate at the University of the South Pacific. He holds his degrees in Mechanical Engineering (B-EngTech and MSc). His expertise cover energy efficiency and management, thermodynamics and refrigeration, climate change mitigation and renewable energy.

Sarah Louise Hemstock holds a PhD in Bioenergy Systems Modelling and is an author and adviser to the Alofa Tuvalu "Small Is Beautiful" project recognised by UNESCO as one of its "Decade of Achievement Projects". Currently she leading the European Union Pacific Technical Vocational Education and Training on Sustainable Energy and Climate Change Adaptation Project (EU PacTVET) at the Secretariat of the Pacific Community, is an Adjunct Fellow of the University of the South Pacific and Visiting Fellow at Nottingham Trent University. In 2010, she was made Government of Tuvalu Honorary Ambassador - Officer for Environmental Science.

Antoine De Ramon N'Yeurt obtained his $\mathrm{PhD}$ in Marine Botany from the University of the South Pacific (USP, Suva) in 1998, and is currently a Lecturer in climate-change issue at the Pacific Centre for Environment and Sustainable Development (PACE-SD) of the University of the South Pacific in Fiji. For the last 20 years he devoted his activities to the study of marine algae of the Pacific Islands such as Fiji, Rotuma, the Cook Islands, and has been involved in surveys of the marine floras of French Polynesia, Wallis, the Solomon Islands, Santo (Vanuatu), the Seychelles and Clipperton.

Dinesh Surroop is a Senior Lecturer at the Department of Chemical and Environmental Engineering, Faculty of Engineering, University of Mauritius, Reduit, Mauritius. He has extensive research experience in energy systems of the Small Island Developing States (SIDS). His field of expertise is energy systems, energy management, waste to energy and alternative energy.

\section{Introduction}

Fijian sugar producers are more likely to face increasing difficulties owing to competitions in their sugar markets and the likely reduction in the price of export sugar owing to the announcement by the EU that the current sugar quota for ACP countries including Fiji will end in September 2017 (Chaudhary, 2013; Sugar Online, 2015). This has encouraged developing countries like Fiji to analyse the prospect of generating substantial income to support the industry from other uses of sugarcane such as ethanol production and exporting electricity from cogeneration to the grid. This will also be consistent with the global initiative of climate change mitigation by reducing greenhouse gas (GHG) emissions, as the production of ethanol and enhanced cogeneration facilities to export power to electricity grid will replace the amount of fossil fuels usage in Fiji. A study carried out by Chandra and Hemstock (2015) reveals that sugarcane in Fiji has a 
theoretical energy potential of 29.8 PJ from sugarcane residue (SCR) consisting of bagasse, tops and leaves and 12.8 PJ from food (consumed as sugar). The study also highlighted that $59 \%$ of total biomass energy available in Fiji was from sugarcane alone. In Australia, sugarcane is recognised as the largest potential source of useful biomass, which can contribute significantly to renewable energy and mitigate country's GHG emissions (Renouf et al., 2013). Sugarcane has a huge global potential, with low investment. Brazil was able to increase ethanol production and productivity, cogeneration and food production in large scale, with policy support and improved management practices. The Fiji Sugar Corporation (FSC) and the Government of Fiji are committed to support the sugarcane industry owing to its socio-economic importance and the industry's potential to produce sugarcane-based clean and renewable energy (Agritrade, 2013; Bainimarama, 2013; ACP, 2013). Sugarcane ethanol is produced extensively in Brazil, which was the largest producer of ethanol until 2005 and is still the largest exporter of ethanol in the world. Sugarcane has more ethanol yield than corn, as sugarcane can produce $45 \%$ more ethanol from the same land area (Crago et al., 2010). The development of sugarcane bioenergy industry does not pose any land threat or food security issues for Fiji, as some land that was once under sugarcane is now idle owing to the expiration of native land leases. In the year 2000, the total land area harvested was 66,000 ha but from 2000 to 2013, the total land area harvested (hectares) declined by $42 \%$ (Fiji Bureau of Statistics, 2015a) and these lands are either idle or used for some other purpose. Even though there are land tenure issues, such as difficulties in getting lease renewed, which brings insecurity to farmers, diversification will increase the current sugarcane price offered to farmers, provide added employment and will help to reduce the importation cost of motor spirit, which will lead to safer sources of energy for our environment.

From 2001 to 2014, the total registered vehicles annually in Fiji increased by 59\% (Fiji Bureau of Statistics, 2015b). This increased the demand for petroleum-based fuels, which are currently imported. In 2014, Fiji imported 876 million litres of petroleumbased fuel as shown in Figure 1. This not only has an impact on the economy and foreign exchange, but also has adverse impact on the environment.

To reduce the dependence on conventional energy, Fiji is empowering itself to use renewable energy sources comprising hydropower, solar, wind, biomass (bagasse) and the biofuel. As depicted in Figure 2, the energy demand in transport sector is the largest category, representing $42 \%$ of total consumption because transportation does include a lot of sea transportation as Fiji is made of 300 islands of which 110 islands are inhabited and this requires a lot of sea transportation. In addition, heavy trucks are used to transport sugarcane to mills during crushing season and most of the time they travel long distances. These could be the reasons why transportation has the highest energy demand. The substitution of fossil fuels for transportation by renewable resources such as biodiesel (from coconut oil) and bioethanol (from sugarcane) can relatively have large impact on the reduction of Fiji's GHG emissions. Currently, Fiji has seven biodiesel plants, which have commissioned the islands of Koro, Rotuma, Cicia, Vanuabalavu, Lakeba, Rabi and Gau. These mills were set up to support the communities in terms of providing consistent supply of clean green fuel, which will uplift the standard of living through the provision of economic activity associated with the mill. These plants are producing biofuel from copra (DOE, 2015). However, production of bioethanol is still at 'feasibility study' stage in Fiji. The main source of feedstock identified for bioethanol is molasses; however, 
ethanol potential from sugarcane juice is also briefly analysed in this paper. Currently, molasses is $95 \%$ exported and remaining is used locally (Khan, 2011).

In consideration of this, along with the need for energy security and the need for securing stable future for Fiji's sugar industry, an interest is generated in local sugar industry and in stakeholders to consider using the facilities available or implement new facilities in local mills to produce ethanol and electricity. In regard to this, FSC has commissioned a new cogeneration plant in the Labasa mill, which will generate $10 \mathrm{MW}$ and is expecting to operate a 40-MW cogeneration plant in Rarawai mill by 2017 (Peters, 2015; FSC, 2015; Drauna, 2015). However, the plans to generate bioethanol are still in the study and planning stage.

Figure 1 Details of fuel import in 2014 (see online version for colours)

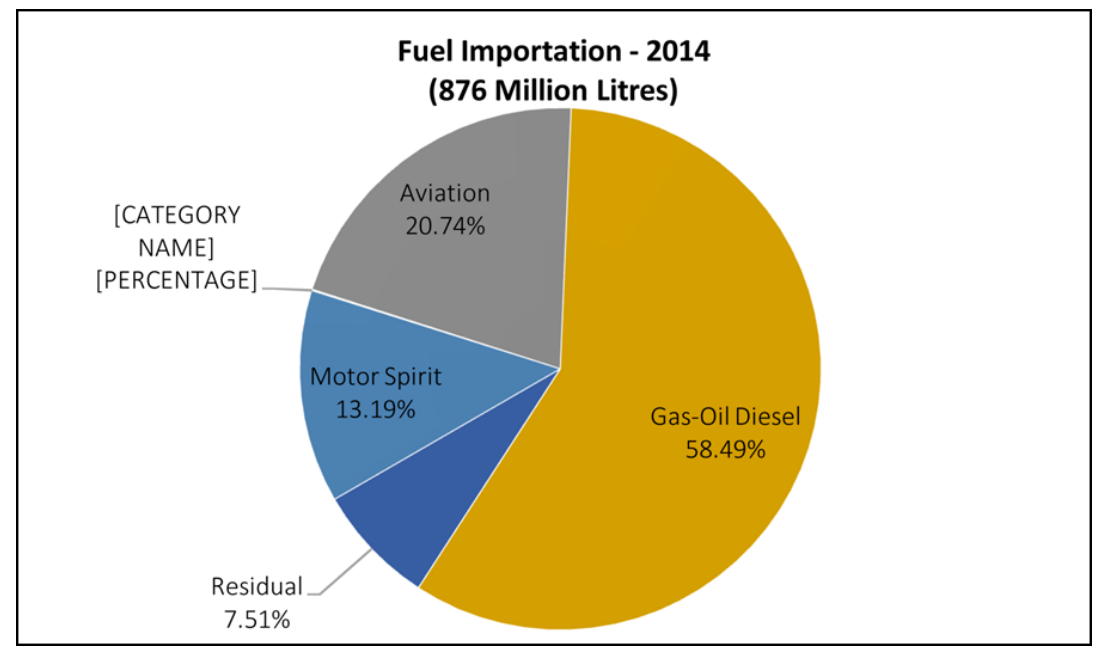

Source: Fiji Bureau of Statistics (2014)

Figure 2 Energy Consumption by Sector in Fiji (see online version for colours)

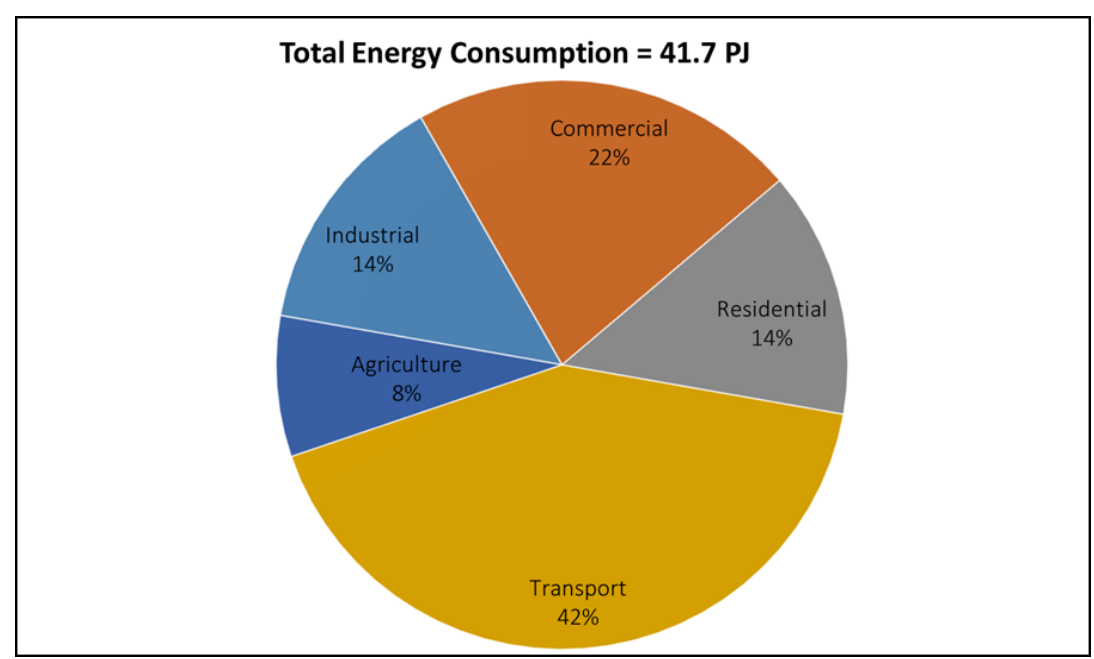

Source: Chandra and Hemstock (2015) 
The five-year annual average production from year 2010 to year 2014 was 1.82 million tonnes as presented in Figure 3. It was noted that Rarawai mill located in Ba has the highest production. Labasa, which is the only mill in the northern island of Fiji known as Vanua Levu, has significant production contribution and the farmers in Labasa are heavily dependent on the sugarcane industry. Diversification into energy generation will have significant impact on these four areas and even if the Penang mill (in Rakiraki) is not upgraded for energy diversification at the initial stage looking at its production rate, the feedstock for energy generation can be transported to the very nearby Penang mill for processing. Most importantly, it should be noted that except Lautoka mill, which is located in Lautoka city, the other three mills are located in the small towns, which are heavily driven by agricultural sector. Thus, any improvement in the income of farmers will have significant impact on the livelihood of many in these areas.

A study carried out in Nepal reveals that molasses-based ethanol (MOE) has net energy value (NEV) of $-13.05 \mathrm{MJ} / \mathrm{L}$ and net renewable energy value (NREV) of $18.36 \mathrm{MJ} / \mathrm{L}$. The positive value of NREV indicates that a low amount of conventional fuels are needed to produce $1 \mathrm{~L}$ of MOE but a negative NEV indicates that the total energy required (both fossil and renewables) to produce ethanol is greater than its own final energy content. It was also observed that the renewable energy contribution amounts to $91.7 \%$ to produce $1 \mathrm{~L}$ of MOE since most of the operations are running with the use of bagasse and biogas except in sugarcane farming where fossil fuels are used (Khatiwada and Silveira, 2009).

Figure 3 2010-2014 average sugarcane production by location (see online version for colours)

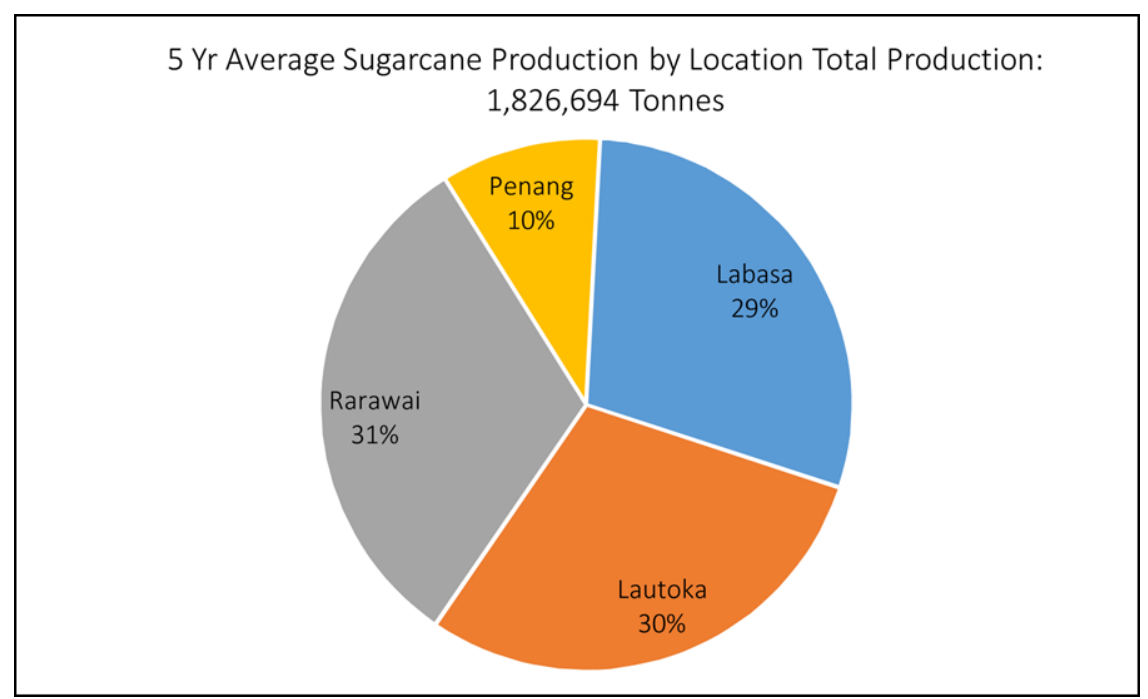

Source: Naidu (2015)

The life-cycle study carried in Malawi reveals that the GHG emission from sugarcane ethanol production is $0.116 \mathrm{kgCO}_{2 \mathrm{eq}} / \mathrm{MJ}$ of ethanol. It was discussed that to improve the carbon footprint, the treatment of vinasse (spent wash) stored in open ponds should be discontinued, as this releases large amount of methane (Dunkelberg et al., 2013). Instead, methane should be stored as biogas for other energy use. In Brazil, vinasse was used in sugarcane cultivation areas by an environmentally controlled fertirrigation process, which 
eliminated the need for potash fertilisers (Coelho et al., 2006). However, another study carried out (Moraes et al. in Sarker et al. (2016)) states that in sugarcane-based plants, the anaerobic digestion of vinasse for biogas use could have higher profits than use in traditional fertirrigation. Therefore, both options can be opted for Fiji. A study carried out in Mexico indicates that the GHG emissions from sugarcane ethanol is $36.8 \mathrm{kgCO}_{2 \mathrm{eq}} / \mathrm{GJ}$ and in Brazil is $27.5 \mathrm{kgCO}_{2 \mathrm{eq}} / \mathrm{GJ}$ and indicates that major contributors of these emission are related to farming practices. Different farming practices will have different emissions (García et al., 2011). All other energy used to produce ethanol are from bagasse and biogas, which are both renewable and by-product of sugar and ethanol.

The similar emissions are expected to be in Fiji as well for ethanol; however, these emissions are still taking place with the current farming practices with no ethanol production. The aim of this paper is to study how sugarcane can positively contribute to the economic and the environment if we utilise the current products of sugarcane, which are molasses and juice to produce ethanol without affecting the local consumption of sugarcane and molasses. More specifically, this paper looks at economic benefits, emission mitigation potential and contribution towards reduction in the use of nonrenewable energy (NRE) by use of sugarcane products to produce energy. The preparation towards production of ethanol will not change the farming practice, which is assumed to be the major GHG emission contributor in the life cycle of ethanol as noted in the literatures. However, it is anticipated that ethanol production from sugarcane (molasses or juice) will have a positive impact on the NREV and this will also reduce the GHG emissions. However, by-products of ethanol, which is vinasse (spent wash), have to be treated or digested in a manner that can boost the NREV by production of (methane) biogas (Moraes et al., 2015).

\section{Methods}

\subsection{Overview}

Three cases as represented in Figure 4 were studied for producing bio-materials, biofuels and bio-energy from Fiji's sugarcane. The first case is a reference case (existing case) and other two are hypothetical (proposed). The changes in the economic benefit and environmental impacts that could result from the implementation of the two proposed cases were analysed relative to the reference case. The reference case is based on current sugarcane production process practised in Fiji. The sugarcane production in Fiji is based on advance cropping practice, which includes use of machine for land preparation, crop cultivation and harvesting, use of fertilisers, application of chemicals to control weeds as well as the use of traditional practices where bullocks are used for land preparation, cultivation and manual cane harvesting.

The proposed cases are hypothetical; established to test the economic feasibility including environmental effects of diversification. Case-1 was proposed with consideration that the current sugar production for local consumption and export will take place as usual. The production of molasses will be as usual but instead of current export, these molasses will be converted into ethanol for local consumption and the existing local consumption of molasses will be as usual. Case-2 was proposed with consideration that sugar and molasses will be only produced for local consumption. The surplus cane juice will be used to produce ethanol directly, which will be used locally and exported. 
The aim of these hypotheses is to understand how value-adding to molasses and using juice to produce ethanol will affect the Fijian economy and the environment. The existing scale of cane growing and the cane-growing practices will remain unchanged, as diversified cases only involve utilisation of co-products. The diversified case also does not alter the local consumption requirement of sugar and molasses.

Figure 4 Process diagram for reference case and proposed diversified cases
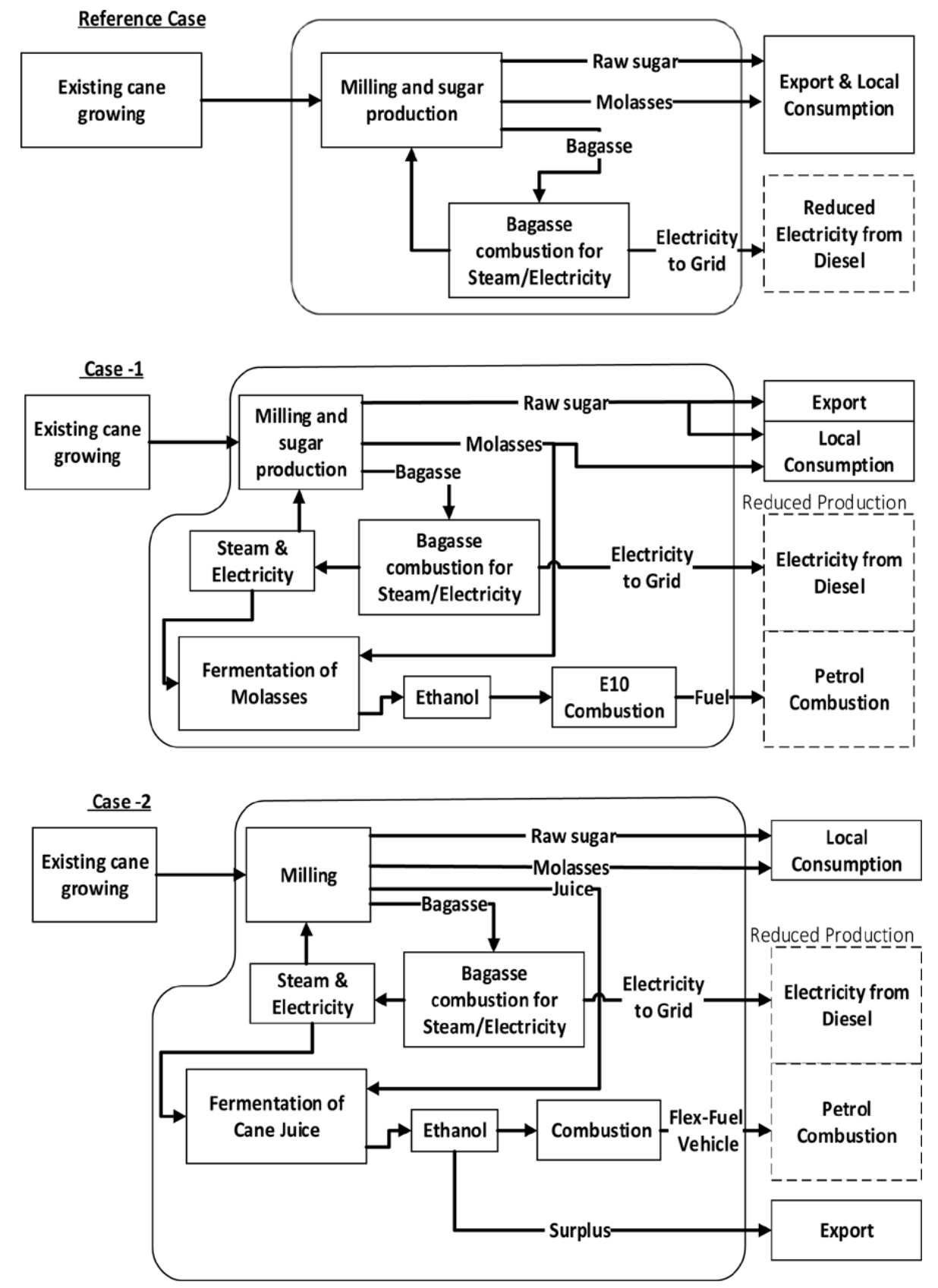
The theoretical analysis of Case-1 was carried out by analysing the amount of molasses exported and its contribution to the economy and alternative calculations were carried out to estimate how much ethanol could be produced instead of exporting molasses. The importation of motor spirit was also considered and analysed to quantify how much ethanol will be required for an E10 blending on the imported motor spirit. The surplus ethanol after $10 \%$ blending is considered for export at the current market price and the replaced motor spirit (10\%) is calculated as a reduction in the use of NRE and in import bills. Ten percentage ethanol blend in gasoline does not require any engine changes. The industrial cost for production of ethanol was also considered and the overall income generated by production and blending of ethanol from molasses was compared with the income generated by exporting of molasses and how it will affect the GHG emissions. Case-2 was analysed in consideration that local consumption of molasses and sugar will remain unchanged and instead of producing sugar for export, the juice will be used for production of ethanol. The produced ethanol will be used locally in the introduced flex-fuel vehicles and the surplus will be exported. It is assumed that the flex-fuel vehicles will run on ethanol, which will reduce the demand of the motor spirit.

\subsection{Data sources}

The following approach was utilised to estimate the total theoretical ethanol potential:

- Data on sugarcane and molasses production were obtained from FAOSTAT (2016), FSC (Khan, 2011) and Fiji Bureau of Statistics $(2011,2013)$.

\subsection{Production data (Sugarcane and molasses)}

Sugarcane and molasses production data consist of annual average for the years 2003-2012 (FAOSTAT, 2016). Using other sources (Fiji Bureau of Statistics, 2013; Khan, 2011), the data sources were verified to provide more inclusive assessment. Production data of bagasse, press-mud, sugar and molasses were obtained from local sugar mill's production departments:

- 10 -year annual average sugarcane yield is $45 \mathrm{t} \mathrm{ha}^{-1}$

- Bagasse\% of cane: $24-30 \%$ varies on cane quality, variety and growing conditions (Charan, 2015)

- Press-Mud\% of cane: $2-5 \%$ varies on the quality of cane, i.e., extraneous matter coming in with the cane in the form of trash, roots and dirt (Charan, 2015)

- Tonnes cane to tonnes sugar ratio (TCTS): 7-10 tonnes cane required to make 1 tonne sugar depending on cane quality and factory efficiencies (Charan, 2015).

- Molasses\% of cane: $3.5-7.0 \%$ depending on impurity loading and quality of cane (Charan, 2015). 


\subsection{GHG emission factors}

The following GHG emission factors presented in Table 1 are obtained from works published previously. In this paper, the average of three gasoline GHG emission factors $\left(2.91 \mathrm{kgCO}_{2 \mathrm{eq}} / \mathrm{L}\right)$ will be used.

Table 1 Production and Combustion-GHG Emission Factors for different fuels

\begin{tabular}{|c|c|c|c|}
\hline \multirow{2}{*}{$\frac{\text { Description }}{\text { Gasoline }}$} & \multicolumn{3}{|c|}{ GHG emission factors $\left(\mathrm{kgCO}_{2 \mathrm{eq}} \mathrm{L}^{-1}\right)$} \\
\hline & $\begin{array}{l}3.00 \text { (Nguyen et al., } \\
2010)\end{array}$ & $\begin{array}{l}2.813 \text { (Khatiwada and } \\
\text { Silveira, 2009) }\end{array}$ & $\begin{array}{l}2.918 \text { (Silalertruksa and } \\
\text { Gheewala, 2010) }\end{array}$ \\
\hline $\begin{array}{l}\text { Sugarcane molasses } \\
\text { based ethanol }\end{array}$ & $\begin{array}{l}0.685 \text { (Silalertruksa and } \\
\text { Gheewala, 2010) }\end{array}$ & $\begin{array}{l}0.435 \text { (Khatiwada and } \\
\text { Semida, 2011) }\end{array}$ & - \\
\hline $\begin{array}{l}\text { Sugarcane juice based } \\
\text { ethanol }\end{array}$ & $\begin{array}{c}0.256 \text { (Silalertruksa and } \\
\text { Gheewala, 2010) }\end{array}$ & - & - \\
\hline
\end{tabular}

\subsection{General assumptions}

The following assumptions apply throughout unless otherwise stated.

- Only sugarcane and molasses were considered for ethanol production. Bagasse is only used for cogeneration.

- Molasses contains around $50 \%$ of sugar content during fermentation by yeast, and ethanol yields per unit mass of molasses feedstock is assumed as 11 of ethanol requires $4 \mathrm{~kg}$ of molasses as feedstock $\left(250 \mathrm{~L} \mathrm{t}^{-1}\right)$ (Silalertruksa and Gheewala, 2010; Nguyen et al., 2009).

- Ethanol yield per unit mass of sugarcanes is assumed, as $1 \mathrm{t}$ of sugarcane can produce a minimum of $70 \mathrm{~L}$ of ethanol (Silalertruksa and Gheewala, 2010; Sriroth, 2011; Thammanomai, 2014).

- Local consumption of molasses and sugar is approximately 5423 and 30,000 t, respectively (FBC, 2012; Khan, 2011).

- The energy content of $1 \mathrm{~L}$ of ethanol is equal to $0.65 \mathrm{~L}$ of gasoline and gasoline's fuel-cycle GHG emissions are assumed to be $2.918 \mathrm{kgCO}_{2}$ eq. $\mathrm{L}^{-1}$ (Silalertruksa and Gheewala, 2010; Nguyen et al., 2007).

- Energy content of gasoline: $32.19 \mathrm{MJ} \mathrm{L}^{-1}$ and ethanol: $21.8 \mathrm{MJ} \mathrm{L}^{-1}$ (Khatiwada and Semida, 2011).

- $\mathrm{GHG}$ emission from burning of: diesel is $0.982 \mathrm{kgCO}_{2 \mathrm{eq}} \mathrm{kWh}^{-1}$, bagasse is $0.025 \mathrm{kgCO}_{2 \mathrm{eq}} \mathrm{kg}^{-1}$ (Khatiwada and Semida, 2011) or $0.0009 \mathrm{kgCO}_{2 \mathrm{eq}} \mathrm{kWh}^{-1}$ (Ramjeawon, 2008; Khatiwada et al., 2016; Khatiwada and Semida, 2011) and trash: $0.087 \mathrm{kgCO}_{2 \mathrm{eq}} \mathrm{kg}^{-1}$ (Khatiwada et al., 2016; Macedo et al., 2008).

- GHG emission from producing raw sugar: $0.55 \mathrm{kgCO}_{2 \mathrm{eq}} \mathrm{kg}^{-1}$ (Yuttitham et al., 2011).

- $1 \mathrm{USD}=2 \mathrm{FJD}$. 


\section{Results and discussion}

\subsection{Sugarcane and molasses production}

Average annual production of Fijian sugarcane for 10 years (2004-2013) totalled $2,309,500 \mathrm{t}$; however, it was noted that from 2006 to 2010 the sugarcane production declined continuously. The immediate three-year annual average from 2013 totalled $1,750,666 \mathrm{t}$ and it represents realistic production ability of the sugar industry for at least next couple of years. Molasses and sugar percentage of cane were inversely proportional, and from 2010, the production of sugar from cane (conversion) was noted to be continuously increasing; however, the sugarcane and molasses production noted an overall decline. A significant decline in production of sugarcane was noted after 2006 as shown in Figure 5 and this could be the result of political instability in the country.

Field study in Labasa (northern island of Fiji) indicated that the decline in sugarcane production in this region was not only due to land lease renewal issues but also the cost of farming (labours, fertilisers, land preparation) had increased. The most important problem is shortage of cane cutters. Overall, the farmers are expecting higher payment per tonne of cane to be profitable, which might attract new farmers or retain existing farmers and encourage them to achieve long-term production improvements. Therefore, diversification of sugarcane into bioenergy generation will lead to more income for the farmers, which will be encouraging to new and young farmers to invest in sugarcane farming leading to increase in the sugarcane production. The implication of increased production would be beneficial to the industry, as this would increase energy generation through burning of bagasse and increased molasses production, which would be used for ethanol production. The major implication would be creation of employment and improved livelihood of ordinary population dependent on sugarcane industry.

Figure 5 Production details in Fiji (see online version for colours)

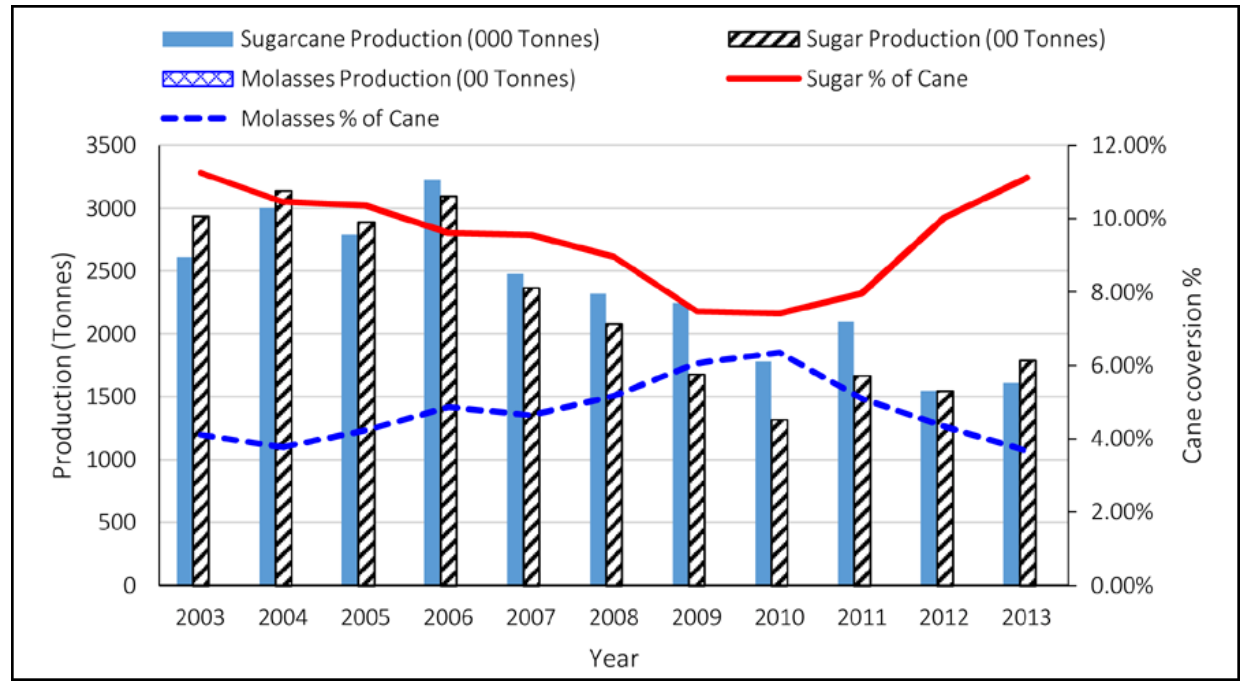




\subsection{Ethanol production potential}

The ten-year annual average ethanol production from sugarcane juice totalled $143,815,000 \mathrm{~L}$ as represented in Figure 6, which also accounts for the production of 30,000 t of sugar for local consumption, which will be extracted from the sugarcane juice before the rest is converted to ethanol. In comparison, the ten-year annual average for ethanol from molasses totalled 26,269,250 L, which also accounts for $5423 \mathrm{t}$ of molasses for local consumption. Figure 6 represents the ethanol production potential from the two feedstocks. The choice of converting molasses to ethanol is preferred when compared with sugarcane juice because ethanol from molasses will meet the $10 \%$ blending demands with the surplus exported until such time as the ethanol demand cannot be met by molasses alone. Also, Fiji is still exporting sugar, which is the backbone of the industry. Should the price of sugar fall below the level needed for industrial profitability, Fiji can start producing ethanol from sugarcane juice. However, the trend shown in Figure 6 depicts that the sugarcane production is continuously declining and this will affect our potential for ethanol if not maintained or improved with current production rate.

On the other hand, to establish the ethanol requirement in Fiji (E10 blend), it was noted that Fiji imported an average of 92.2 million litres of motor spirit annually (10-year annual average) as shown in Figure 7, and looking at the possibility of a $10 \%$ ethanol blend (E10) with motor spirit from locally produced ethanol from molasses, Fiji can reduce imports by 9.2 million litres of motor spirit if current practices are assumed to continue in future. Considering the 2014 cost of importation ( $\$ 1.48 / 1$ of motor spirit), Fiji can save approximately $\$ 13.7$ million dollars in foreign currency. Figure 7 represents the 10 -year import quantity for motor spirit with forecast up to year 2020, which indicates that the demand for motor spirit will continue to increase as a result of increasing imports of motor vehicles. The imported motor spirit is forecasted to increase from 2014 to 2020 by $17.6 \%$. This means that the carbon emissions (2014-2020) will increase by 59,572 tonnes of $\mathrm{CO}_{2 \mathrm{eq}}$.

Figure 6 Ethanol production potential in Fiji (see online version for colours)

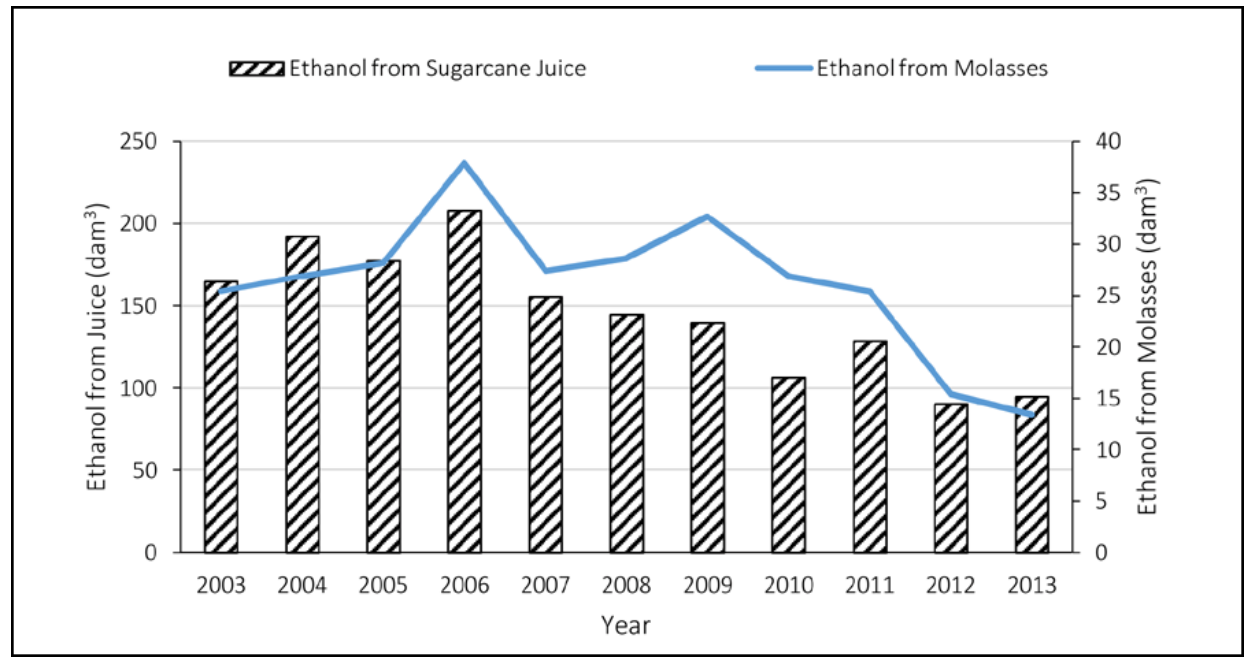


Figure 7 Details of ethanol requirements and motor spirit blending (E10) in Fiji (see online version for colours)

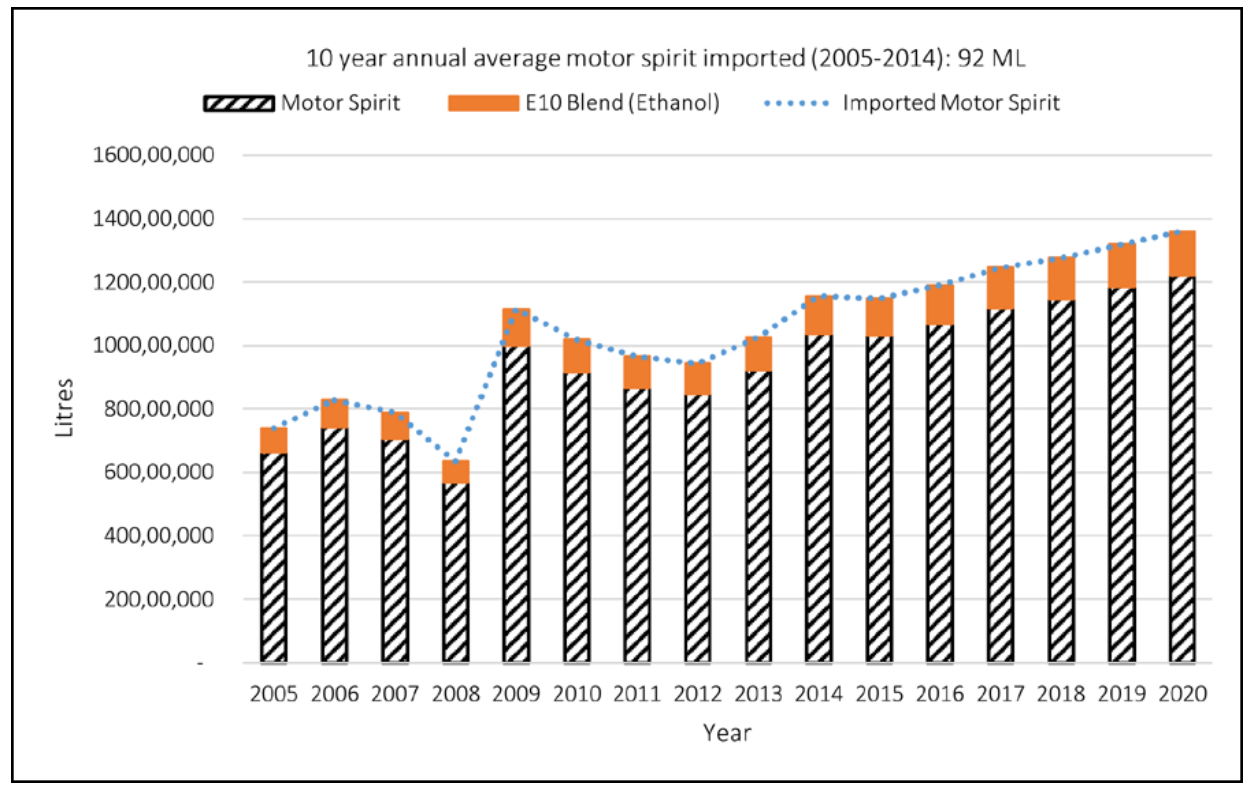

Annual average (2010-2014) production as shown in Table 2 indicates that Fiji has exported molasses at a price of FJ $\$ 20,245,000$ and converting this into ethanol could generate value of FJ\$27,508,565. This is a result of saving on the importation of motor spirit (on the landed cost of motor spirit) by having E10 blend and the surplus can be exported or sold for other usage. Molasses to ethanol industrial cost (excluding feedstock cost) was also taken into consideration and described in Table 2. The profit of FJ\$ 7.2 million from ethanol conversion is equivalent to employing 450 employees at above poverty threshold (FJ $\$ 16,000)$. Since molasses is a by-product of the sugar process and can be regarded as available to factory without added current cost, only refinery/conversion cost from the published literature is taken into consideration. This cost is assumed to have included costs of labour, operations and maintenance. However, a significant amount of capital investment would be needed to upgrade factories and install state-of-the-art equipment. The assumed capital costs for an ethanol distillery are in the range of FJ\$100-160 million (Hira, 2011; García and Manzini, 2012). Since Fiji has four sugar mills, it would be uneconomical to install four ethanol distilleries. Therefore, the distillery plant could be installed in Penang or Rarawai mill. Since Penang is the least sugarcane processing mill and any production improvement will create employment in that area, however, the disadvantage would be that this mill will not have enough steam to meet the demands of a distillery plant compared with Rarawai mill, which is processing the largest sugarcane and is expected to have enough bagasse since this mill is not exporting the surplus electricity to grid. The other two mills, Labasa and Lautoka, are exporting electricity to grid.

The current fuel standards in Fiji specify that petrol (gasoline) can contain 10\% volume by volume ethanol maximum (Trade Standards, 2007) but at present the fuels imported do not contain ethanol. Fiji has recently introduced hybrid cars and the introduction of flex-fuel vehicles should also be considered by the authorities if Fiji 
wants to develop and sustain its ethanol industry. The present demand of ethanol (E10 blend) can easily be met by molasses, which is currently exported. Fiji currently imports 115.5 million litres of motor spirit. The ethanol required for an E10 blend can easily be met by ethanol produced from molasses derived from current sugarcane production if the revised policy and flex fuel vehicles are introduced. Table 4 shows fiveyear average of the ethanol production potential from proposed Cases-1 and 2. The current exportation of molasses and sugar generates around FJ\$168 million. However, the use of sugarcane juice (case-2) will produce 106,246,000 million litres of ethanol having an export value of FJ\$ 184.4 million and conversion cost of FJ\$ 34.2 million.

\subsection{GHG emissions and mitigation potential}

Sugarcane involves many processes from cultivation to milling, which results into substantial emissions; however, these emissions can be mitigated using advanced technologies to displace the use of NRE with the use of sugarcane-based energy. The emissions result from the use of machines for land preparation, fertilisers for growth, transportation and milling. Burning of cane and trash is a problem as well, but it does not have real net effect on the emissions. This section will focus only on environmental impacts of cane burning, bagasse combustion and production of ethanol using proposed cases-1 and 2 (Figure 4) though cane burning and bagasse combustion does not have net effect on emissions, as this $\mathrm{CO}_{2}$ emitted will be re-absorbed by the next crop.

On an annual average (2010-2014), 1,772,944 $t$ of sugarcane was produced and $29 \%$ of cane was burnt before harvest, which emitted $6262 \mathrm{tCO}_{2 \mathrm{eq}}$. Mostly, these canes were not burnt by farmers but were the act of others. Farmers are noted to be hesitant in burning their cane because it required immediate harvesting and transportation to mill, which is sometimes very difficult, and as a result, burnt cane does not attract optimum payment. On the other hand, it was noted that approximately 35\% farmers burned the trash after cane harvest, which emitted $5366 \mathrm{tCO}_{2 \mathrm{eq}}$. The rest of the trash is left in the field for mulching and decomposition, which emitted $2061 \mathrm{tCO}_{2 \mathrm{eq}}$.

Second, a total of 531,883 t of bagasse was also produced in the process of producing sugar. The bagasse was used in combustion for sugar processing as well for cogeneration. In this process, $13,297 \mathrm{tCO}_{2 \mathrm{eq}}$ was emitted. Owing to lack of data available, it is was difficult to determine how much energy was produced from bagasse for grid electricity, but it is assumed that similar emissions from bagasse will occur for proposed cases- 1 and 2; however, the trade-offs of bagasse-powered electricity need to be considered that reduces the use of diesel and its associated emissions.

Moreover, the environmental impact of converting sugarcane molasses and juice into ethanol is represented in Tables 3 and 4, respectively. A negative result in Table 4 indicates an environmental benefit or reduction in usage relative to reference case whereas a positive result indicates an actual impact and usage for that particular case. The majority of the water and land are linked with cane growing, and in this study the focus is only on diversification process, which involves industrial process. In ethanol production (industrial process), water will be required in the following process: juice cooling $1 \mathrm{~m}^{3} \mathrm{tc}^{-1}$, fermentation cooling $3 \mathrm{~m}^{3} \mathrm{tc}^{-1}$ and condenser cooling $4 \mathrm{~m}^{3} \mathrm{tc}^{-1}$ (Moreira, 2007). 
Table 2 Potential implication of converting molasses into ethanol - Case 1

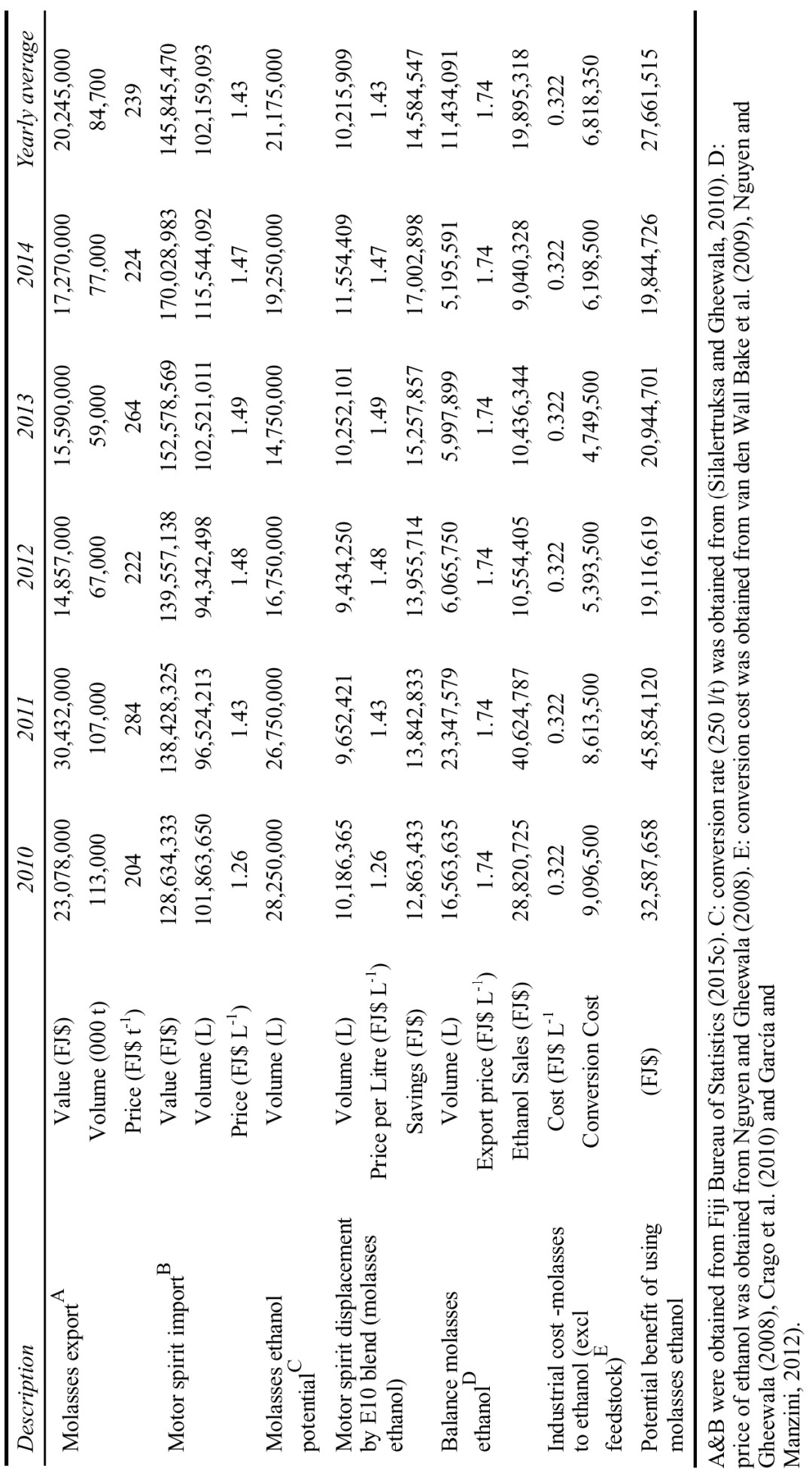


Table 3 Carbon emission and mitigation potential of case 1

\begin{tabular}{lccccc}
\hline Year & $\begin{array}{c}\text { Use of } \\
\text { imported motor } \\
\text { spirit }\left(\mathrm{tCO}_{2 \mathrm{eq}}\right)\end{array}$ & $\begin{array}{c}\text { Production of } \\
\text { ethanol for } \\
10 \% \text { blending } \\
\left(\mathrm{tCO}_{2 \mathrm{eq}}\right)\end{array}$ & $\begin{array}{c}\text { Use of } 90 \% \\
\text { motor spirit } \\
\left(\mathrm{tCO}_{2 \mathrm{eq}}\right)\end{array}$ & $\begin{array}{c}\text { Use of blended } \\
\left(\begin{array}{c}\text { E10) fuel } \\
\left(\mathrm{tCO}_{2 \mathrm{eq}}\right)\end{array}\right.\end{array}$ & $\begin{array}{c}\text { Total saving } \\
\text { from using E10 } \\
\text { fuel }\left(\mathrm{tCO}_{2 \mathrm{eq}}\right)\end{array}$ \\
\hline 2010 & 296,423 & 6978 & 266,781 & 273,758 & 22,665 \\
2011 & 280,885 & 6612 & 252,797 & 259,409 & 21,477 \\
2012 & 274,537 & 6462 & 247,083 & 253,545 & 20,991 \\
2013 & 298,336 & 7023 & 268,503 & 275,525 & 22,811 \\
2014 & 336,233 & 7915 & 302,610 & 310,525 & 25,709 \\
Yearly average & 297,283 & 6998 & 267,555 & 274,553 & 22,730 \\
\hline $\mathrm{A}$ & & &
\end{tabular}

$\mathrm{A}=$ Tonnes of $\mathrm{CO}_{2}$ emission from use of all motor spirit imported in Fiji. $\mathrm{B}=$ Tonnes of $\mathrm{CO}_{2}$ emission from production and use of $10 \%$ ethanol extracted from Molasses which will be blended to imported motor spirit. $\mathrm{C}=$ Tonnes of $\mathrm{CO}_{2}$ emission from production and use of motor spirit $(90 \%)$ that will be blended with $10 \%$ local ethanol. $\mathrm{D}=$ Tonnes of $\mathrm{CO}_{2}$ emission from production and use of blended fuel $(10 \%$ ethanol \& $90 \%$ Motor Spirit). $\mathrm{E}=$ Tonnes of $\mathrm{CO}_{2}$ emission that can be avoided by motor spirit $90 \%$ - ethanol $10 \%$ blending.

Table 4 Impacts of diversified industry scenario relative to the reference case

\begin{tabular}{lcccc}
\hline & \multicolumn{4}{c}{ Annual Average (2010-2014) Sugarcane Production: $1,772,944 t$} \\
\cline { 2 - 5 } Description & Units & Reference case & Case - 1 & Case - 2 \\
\hline Products of Sugarcane & $\mathrm{t}$ & 172,258 & 172,258 & 30,000 \\
Sugar & $\mathrm{L}$ & - & $19,826,500$ & $106,246,000$ \\
Ethanol & $\mathrm{t}$ & 84,729 & 5423 & \\
Co-products & & & & 5423 \\
Molasses & $\mathrm{L}$ & $102,159,093$ & $-10,215,909$ & $-102,159,093$ \\
Other Usage/Emissions & $\mathrm{TJ}$ & 3289 & -329 & -3289 \\
Gasoline & $\mathrm{t}$ & 297,283 & $-22,730$ & $-270,084$ \\
Non-Renewable Energy & & & & \\
GHG emissions from Gasoline & $\mathrm{tCO}$ & &
\end{tabular}

This indicates that $14,183,552 \mathrm{~m}^{3}$ of additional water is required for ethanol production as proposed in diversified cases. However, this does not add to water footprint, as water is recycled in all these processes. On the other hand, a study carried out by Renouf et al. (2013) indicates that ethanol produced from molasses will have $-0.017 \mathrm{~m}^{3} \mathrm{tc}^{-1}$ impact on water footprint, as wastewater is treated in the process. Therefore, it is assumed that the diversified cases proposed do not affect water footprint.

The production of ethanol and blending with imported motor spirit will lead to substantial saving in GHG emissions as presented in Tables 3 and 4, respectively. The current use of imported motor spirit is emitting 297,283 $\mathrm{tCO}_{2 \mathrm{eq}}$. Production of local ethanol as proposed in cases-1 and 2 will result in emission of $6998 \mathrm{tCO}_{2 \mathrm{eq}}$ and $27,199 \mathrm{tCO}_{2 \mathrm{eq}}$. However, the net impact on environment considering the production 
of ethanol and displacement of gasoline in proposed cases- 1 and 2 relative to reference case will be $-22,730$ and $-270,084 \mathrm{tCO}_{2 \mathrm{eq}}$, respectively. Likewise for cases-1 and 2, the use of NRE will reduce by $329 \mathrm{TJ}$ and $3289 \mathrm{TJ}$, respectively.

\section{Conclusion}

The two proposed diversified cases studied in this paper show that ethanol produced from both these cases could achieve considerable economical and environmental benefits such as reduction in the use of NRE and reduction in GHG from avoided importation and use of NRE. The proposed scenarios show that shifting from export of molasses to local utilisation for ethanol production can generate additional income of FJ\$ 7.2 million (case-1), which will have positive impact on farmers and will encourage farmers to increase production of sugarcane for higher returns. The increase in sugarcane production will not threat natural forest, as abandoned or underutilised lands will be used first to increase production. In addition, distilleries will provide added jobs, which are much needed for many in Fiji. Vinasse, a by-product of ethanol, could either be used as fertilisers or for the production of biogas. The actual economical and environmental benefits of vinasse usage have not been explicitly discussed in this paper and it can be an important area for future studies. The current income generated from exportation of sugar and molasses can even be sustained if sugarcane juice is diverted to ethanol directly as proposed in case-2. This option presented herein offers large reductions in emissions and use of NRE. However, there is a huge capital cost required for installation of distillery plant but this investment will bring economic stability in the sugar industry. Fiji also needs to strengthen its biofuel policies and focus on introducing compulsory local $10 \%$ blending and flex-fuel vehicles if the sugar industry is focusing on ethanol production with long-term sustainability. It is recommended that further studies should be conducted to discuss explicitly; the capital investment cost needed and how policy change will contribute towards this sustainable development. Sugarcane is noted to have a global potential and sustainable investment. In this regard, Fiji already has established sugar industry, which should be managed and operated towards a global target of diversification of sugar industry into energy industry. Appropriate policies and roadmap need to be devised to realise these goals.

\section{References}

ACP (2013) ACP Ministers for Sugar Tackle Next Steps After EU CAP Reforms, http://www.acp. int/content/acp-ministers-sugar-tackle-next-steps-after-eu-cap-reforms (Accessed 20 March, 2015).

Agritrade (2013) Fiji Preparing for End of EU Sugar Production Quotas?, http://agritrade. cta.int/Agriculture/Commodities/Sugar/Fiji-preparing-for-end-of-EU-sugar-production-quotas (Accessed 20 March, 2015).

Bainimarama, J.V. (2013) Speech at the Opening of the 13th ACP Ministerial Conference on Sugar, http://www.acp.int/sites/acpsec.waw.be/files/Bainimarama_speech.pdf (Accessed 1 May, 2015).

Chandra, V.V. and Hemstock, S.L. (2015) 'A biomass energy flow chart for Fiji', Biomass and Bioenergy, Vol. 72, pp.117-122. 
Charan, N. (2015) Personal Communication with Charan, N., Commoditied from Sugarcane, Email Communication 2015.

Chaudhary, F. (2013) EU Ends Sugar Quota System, http://www.fijitimes.com/story.aspx?id = 248452 (Accessed 17 October, 2014).

Coelho, S.T., Goldemberg, J., Lucon, O. and Guardabassi, P. (2006) 'Brazilian sugarcane ethanol: lessons learned', Energy for Sustainable Development, Vol. 10, No. 2, pp.26-39.

Crago, C.L., Khanna, M., Barton, J., Giuliani, E. and Amaral, W. (2010) 'Competitiveness of Brazilian sugarcane ethanol compared to US corn ethanol', Energy Policy, Vol. 38, No. 11, pp.7404-7415.

DOE (2015) Biofuel Implementation Projects, http://www.fdoe.gov.fj/index.php/energy-security/ biofuel/biofuel-implementation-projects (Accessed 15 May, 2014).

Drauna, P. (2015) FSC Labasa Cogeneration System to Go Online at Start of This Crushing Season, Fiji Sun, http://fijisun.com.fj/2015/04/11/fsc-labasa-cogeneration-system-to-goonline-at-start-of-this-crushing-season/, section.

Dunkelberg, E., Finkbeiner, M. and Hirschl, B. (2013) 'Sugarcane ethanol production in Malawi: Measures to optimize the carbon footprint and to avoid indirect emissions', Biomass and Bioenergy, Vol. 71, pp.37-45.

FAOSTAT (2016) http://faostat.fao.org/ (Accessed 20 January, 2016).

FBC (2012) Imported Sugar for Local Consumption, http://www.fbc.com.fj/fiji/6167/importedsugar-for-local-consumption (Accessed 19 May, 2015).

Fiji Bureau of Statistics (2011) Fiji Facts and Figures 2011-1, www.statsfiji.gov.fj

Fiji Bureau of Statistics (2013) Sugar Industry Production and Prices, http://www.statsfiji.gov.fj/ index.php/economic/5-economic-statistics/economic-general/109-production-index-of-keyindustrial-sectors (Accessed December, 2015).

Fiji Bureau of Statistics (2014) HS Import and Export, http://www.statsfiji.gov.fj/index.php/ search?searchword $=$ import\&ordering $=$ newest\&searchphrase $=$ all

Fiji Bureau of Statistics (2015a) Key Statistics 2014, www.statsfiji.gov.fj

Fiji Bureau of Statistics (2015b) Distribution of Vehicles Registered in Fiji Annually, http://www. statsfiji.gov.fj/statistics/other-statistics/registered-vehicles

Fiji Bureau of Statistics (2015c) Table 9 - Principal Domestic Exports by HS. [online] (Accessed 20, July 2015).

FSC (2015) Bio-Projects (Accessed 12 April, 2015).

García, C.A. and Manzini, F. (2012) 'Environmental and economic feasibility of sugarcane ethanol for the Mexican transport sector', Solar Energy, Vol. 86, pp.1063-1069.

García, C.A., Fuentes, A., Hennecke, A., Riegelhaupt, E., Manzini, F. and Masera, O. (2011) 'Life-cycle greenhouse gas emissions and energy balances of sugarcane ethanol production in Mexico', Applied Energy, Vol. 88, No. 6, pp.2088-2097.

Hira, A. (2011) 'Sugar rush: prospects for a global ethanol market', Energy Policy, Vol. 39, pp.6925-6935.

Khan, A. (2011) Annual Report 2011, http://fsc.com.fj/AnnualReport.html

Khatiwada, D. and Semida, S. (2011) 'Greenhouse gas balances of molasses based ethanol in Nepal', Journal of Cleaner Production, Vol. 19, pp.1471-1485.

Khatiwada, D. and Silveira, S. (2009) 'Net energy balance of molasses based ethanol: the case of Nepal', Renewable and Sustainable Energy Reviews, Vol. 13, pp.2515-2524.

Khatiwada, D., Venkata, B.K., Silveira, S. and Johnson, F.X. (2016) 'Energy and GHG balances of ethanol production from cane molasses in Indonesia', Applied Energy, Vol. 164, pp.756-768.

Macedo, I.C., Seabra, J.E.A. and Silva, J.E.A.R. (2008) 'Green house gases emissions in the production and use of ethanol from sugarcane in Brazil: the 2005/2006 averages and a prediction for 2020', Biomass and Bioenergy, Vol. 32, pp.582-595. 
Moraes, B.S., Zaiat, M. and Bonomi, A. (2015) 'Anaerobic digestion of vinasse from sugarcane ethanol production in Brazil: challenges and perspectives', Renewable and Sustainable Energy Reviews, Vol. 44, pp.888-903.

Moreira, J.R. (2007) Water Use and Impacts Due Ethanol Production in Brazil, www.xitizap.com/ etanol-moreira.pdf (Accessed February, 2016).

Naidu, S. (2015) Personal Communication with Naidu, S., Sugarcane Production by Location, Email, 3 September, 2015.

Nguyen, T.L.T. and Gheewala, S.H. (2008) 'Fuel ethanol from cane molasses in Thailand: environmental and cost performance', Energy Policy, Vol. 36, pp.1589-1599.

Nguyen, T.L.T., Gheewala, S.H. and Garivait, S. (2007) 'Energy balance and GHG-abatement cost of cassava utilization for fuel ethanol in Thailand', Energy Policy, Vol. 35, pp.4585-4596.

Nguyen, T.L.T., Gheewala, S.H. and Sagisaka, M. (2010) 'Greenhouse gas savings potential of sugar cane bio-energy systems', Journal of Cleaner Production, Vol. 18, pp.412-418.

Nguyen, T.L.T., Hermansen, J.E. and Sagisaka, M. (2009) 'Fossil energy savings potential of sugar cane bio-energy systems', Applied Energy, Vol. 86, pp.132-139.

Peters, T. (2015) Personal Communication with Peters, T., Details about Cogeneration, Fiji Sugar Corporation.

Ramjeawon, T. (2008) 'Life cycle assessment of electricity generation from bagasse in Mauritius', Journal of Cleaner Production, Vol. 16, pp.1727-1734.

Renouf, M.A., Pagan, R.J. and Wegener, M.K. (2013) 'Bio-production from Australian sugarcane: an environmental investigation of product diversification in an agro-industry', Journal of Cleaner Production, Vol. 39, pp.87-96.

Sarker, T.C., Azam, S.M.G.G. and Bonanomi, G. (2016) 'Recent advances in sugarcane industry solid by-products valorization', Waste and Biomass Valorization, Vol. Online First.

Silalertruksa, T. and Gheewala, S.H. (2010) 'Security of feedstocks supply for future bio-ethanol production in Thailand', Energy Policy, Vol. 38, pp.7476-7486.

Sriroth, K. (2011) Recent Situation of Bioethanol in Thailand: Policy and Production (Accessed 19 May, 2015).

Sugar Online (2015) Fiji to be Hit Hard by End of EU Quotas in 2017, http://www.sugaronline. com/home/website_contents/view/1239389 (Accessed 20 March, 2015).

Thammanomai, A. (2014) Thailand Biofuel Policies, https://www.iea.org/media/technology platform/workshops/southeastasiabioenergy2014/Thailand.pdf (Accessed 19 May, 2015).

Trade Standards (2007) Trade Standards (Fuel Standards) Order 2007, in Decree No. 24 of 1992-2007, Fiji, pp.191-198.

van den Wall Bake, J.D., Junginger, M., Faaij, A., Poot, T. and Walter, A. (2009) 'Explaining the experience curve: cost reductions of Brazilian ethanol from sugarcane', Biomass and Bioenergy, Vol. 33, pp.644-658.

Yuttitham, M., Gheewala, S.H. and Chidthaisong, A. (2011) 'Carbon footprint of sugar produced from sugarcane in eastern Thailand', Journal of Cleaner Production, Vol. 19, pp.2119-2127. 